\title{
BIOPOLÍTICA NA PERSPECTIVA DE GIORGIO AGAMBEN: DISPOSITIVOS E A VIDA NUA DOS POVOS INDÍGENAS BRASILEIROS
}

Thayse Edith Coimbra Sampaio*

Flávia de Ávila**

RESUMO: O presente artigo busca compreender as manifestações de poder que conduzem o indígena à vida sacra. Todo o aprofundamento acerca da política moderna parte de fragmentos do pensamento agambiano: dispositivo, força-de-lei, iustitium; vida nua e Povo - povo. A análise se inicia com a "suspensão de segurança". Esta escolha se explica pelo papel paradigmático que desempenha na temática indigenista, conduzindo os autóctones a um vazio normativo. Indaga-se: a aplicação do instituto da suspensão de segurança, pelos tribunais de justiça nacionais, em casos envolvendo povos originários, integra o "dispositivo", figura do pensamento de Agamben?

PALAVRAS-CHAVES: Biopolítica. Agamben. Dispositivo. Suspensão de Segurança. Povos Indígenas.

\section{BIOPOLYTICS IN THE GIORGIO AGAMBEN PERSPECTIVE: APPARATUS AND THE NATIONAL LIFE OF THE BRAZILIAN INDIGENOUS PEOPLES}

\begin{abstract}
The present article seeks to understand the manifestations of power that lead the indigenous to the sacred life. All the deepening about the modern politics part of fragments of the agambiano thought: apparatus, force of law, iustitium; naked life and people - people. The analysis begins with the "suspension of security". This choice is explained by the paradigmatic role it plays in the indigenist theme, leading the natives to a normative void. It is questioned: the application of the institute of security suspension, by national courts of justice, in cases involving indigenous peoples, integrates the "apparatus", figure of Agamben thought?
\end{abstract}

KEWORDS: Biopolitics. Agamben. Apparatus. Suspension of Security. Indigenous people.

\footnotetext{
* Mestranda em Direito pela Universidade Federal de Sergipe - UFS. Bolsista da CAPES. Bacharela em Direito pela Universidade Estadual de Alagoas- UNEAL E-mail: thayseedith@hotmail.com.

** Professora do Departamento de Relações Internacionais e do Programa de Pós-Graduação em Direito da UFS. Mestre em Direito pela UFSC. Doutora em Direito pela PUC/MG. E-mail: flaviadeavila@gmail.com.
} 


\section{INTRODUÇÃO}

O corpo político brasileiro é uma tela miscigenada, tingida pelos "moinhos de gastar gente” (RIBEIRO, 2017). Assim, no interior dos desdobramentos que compõe o Povo, ocorre além de outras, a presença indígena, sujeitos que, mesmo integrando a unidade política nacional, são grafados com a insígnia "povo indígena” ou “povo originário”, o que configura em um aspecto identitário, mas ao mesmo tempo segregacional.

Uma busca breve acerca da atuação estatal contemporânea ante as populações originárias, permite ao leitor identificar desproporções em um quadro de relações de poder. Inúmeras iniciativas voltadas ao desenvolvimento econômico do Brasil subjugam os interesses dos povos nativos em detrimento do nacional, inscrevendo na tessitura social uma série de relacionamentos dicotômicos: vencidos - vencedores; miseráveis, oprimidos, banidos soberanos; etc.

Tendo em vista este contexto, o objetivo geral deste artigo é investigar as razões que edificam essa leitura sensorial sobre os indígenas brasileiros, buscando aprofundar o entendimento e compreender o mecanismo biopolítica contemporâneo através de algumas categorias elementares do pensamento de Giorgio Agamben, tais como: dispositivo; força-delei; iustitium; vida nua e Povo - povo.

O ponto inicial dessa análise é a utilização do estatuto da "suspensão de segurança” em decisões liminares favoráveis ao direito das populações aborígenes em processos judiciais que discutem a regularidade legal da execução de empreendimentos econômicos, de grande escala (hidrelétricas e rodovias), em terras tradicionais.

A suspensão de segurança, considerado neste artigo como sendo um “dispositivo” - de controle e subjugação, se materializa em decisões judiciais, um predicado fundante do Direito ao lado da norma, podendo apresentar caráter jurídico ou político, a depender da corrente adotada acerca da natureza da “suspensão de segurança”. Independente da vertente doutrinária empregada, ocorre a interrupção da ordem jurídica por meio de um elemento ancorado no direito, uma vez que apresenta previsão normativa. Portanto, é hipótese excepcional que “estarfora, e ao mesmo tempo, pertence” a um direito normalmente válido (AGAMBEN, 2004). 
Em disputa, existem normas em vigor ${ }^{1}$ que perdem sua força em prejuízo de atos que adquirem potência de lei ou até mesmo uma robustez superior à Constituição Federal. O ponto problemático consiste em um fato que não se subsumi à regra geral, mas o inverso, uma situação concreta que origina uma norma específica, cuja função é assegurar estabilidade ao mandato legal brasileiro, ameaçado por uma circunstância factual.

A medida adotada é considerada imprescindível para salvaguardar a ordem e a segurança jurídica, devido a uma conjuntura que solicita a aplicação de medidas excepcionais. O vazio do Direito, que surge mediante a atuação de juízes e desembargadores, excede os poderes constitucionais que delimitam suas atuações. O cenário de anomia ainda se verifica na indistinção entre os interesses públicos e privados que fundamentam o julgamento.

A escolha deste componente de largada se justifica tanto pelo papel paradigmático que desempenha na temática indigenista, o que conduz os autóctones a um vazio normativo, quanto pela preocupação em se delimitar o objeto proposto neste estudo. Nesse sentido, indaga-se: a aplicação do instituto da suspensão de segurança pelos tribunais de justiça nacionais em casos envolvendo povos indígenas incorpora-se em um "dispositivo", figura do pensamento agambiano?

O presente estudo busca, como meta específica, analisar se o instituto jurídico apresentado nas linhas acima, em casos envolvendo apreciações judiciais liminares favoráveis a povos originários, integra-se a feição de um “dispositivo biopolítico”. A hipótese de trabalho aponta para uma resposta afirmativa. Toda a literatura utilizada será direcionada ao seu teste, visto ser um dos aspectos importantes da pesquisa científica, a possibilidade de rejeição da hipótese mais intensa (RICHARDSON et al., 1985).

O método utilizado será a pesquisa bibliográfica, combinada com a aplicação de análise doutrinária, jurisprudencial e normativa, como técnicas de pesquisa. Entretanto, como todo caminho científico depende da observância de determinadas regras e procedimentos, a metodologia escolhida foi a qualitativa, pois pretende-se compreender e descrever a complexidade dos processos que tolhem os direitos das populações primitivas.

Por fim, as normas e instituições judiciárias se consistem em um conjunto de representações sociais, ou ainda, em um modo singular de enxergar a realidade (SOUZA

\footnotetext{
${ }^{1}$ A Constituição Federal, em específico: artigos 231 e 232; a Convenção 169 da Organização Internacional do Trabalho; Declaração das Nações Unidas sobre os Direitos dos Povos Indígenas; etc.
} 
SANTOS, 1988). Nesse sentido, foi empregue a técnica de pesquisa denominada de análise de conteúdos, "conjunto de instrumentos metodológicos cada dia mais aperfeiçoados que se aplicam a discursos diversos.” (RICHARDSON et al., 1999, p. 223).

\section{O “DISPOSITIVO BIOPOLÍTICO” E OUTRAS CATEGORIAS DO PENSAMENTO DE GIORGIO AGAMBEN}

Os elementos filosóficos que serão apresentados integram a investigação biopolítica desenvolvida pelo autor italiano Giorgio Agamben. As obras que guardam relação com este estudo são: "Meios sem fim: notas sobre a política" (1996); "Estado de Exceção" (2003) e o ensaio "O que é dispositivo?" (2008).

1.1 Dispositivo Biopolítico

A escolha desse elemento para compreender a dinâmica da política contemporânea parte do pensamento foucaultiano, especialmente da acepção “positivé”. É identificado, através do método arqueológico paradigmático empregado por Giorgio Agamben um antigo termo grego, oikonomia, que após a tradução de padres da Alta Idade Média, recebe a denominação que ora é trabalhada (AGAMBEN, 2009).

A igreja adota essa designação para justificar e fazer cessar, internamente, movimentos de resistência à trindade de figuras divinas (Deus - Espírito Santo e o Filho), expondo que não representavam um retorno ao politeísmo na fé cristã (AGAMBEN, 2009). No termo se assinala a gestão da casa (oikos). Assim, Deus quanto a sua essência é uno, porém concernente à administração de sua morada e do mundo que concebeu, é trino.

Essa explicação conduz a teologia a uma incoerência intrínseca, que separa progressivamente em Deus: o ser e a ação. A ação que passa a ser compartilhada para a melhor gestão da vida doméstica não apresenta fundamento no ser. A relação que se estabelece com o dispositivo biopolítico reside no seu emprego sem fundamento em um ente, ocasionando processos de subjetivação.

Essa fratura, que aparta e articula os elementos da divindade superior, está conectada com a ideia de Foucault de "dispositivos", dado que este consiste em todo meio pelo qual se realiza uma atividade de governo sem alicerce na essência. Portanto, é meio que administra e governa o mundo contemporâneo. O que é frequente em todas as expressões mencionadas é a alusão “[...] a um conjunto de práxis, de saberes, de medidas, de instituições, cujo objetivo é 
gerir, governar, controlar e orientar, num sentido que se supõe útil, os gestos e os pensamentos dos homens.” (AGAMBEN, 2009, p. 39).

Em síntese, até o pensamento foucaultiano, esse mecanismo que advém do termo grego comentado nos parágrafos anteriores, consiste em uma unidade/rede, linguística ou não linguística, que se instaura por meio de: leis, medidas de polícia, discursos, instituições, posicionamentos teóricos, etc. Para cumprir uma missão determinada, prestar auxílio aos vínculos de poderio, cruzando relacionamentos de poder, com o saber.

A partir desse fragmento teórico, o estudioso italiano conduz o leitor a uma análise própria, a bifurcação do mundo existente em seres viventes e dispositivos, que expõe a marcha da subjetivação hodierna. As parcelas do universo identificado estão em constante interação, resultando no sujeito (AGAMBEN, 2009). Neste sentido, a formação dos sujeitos é sempre um processo de interrupção pelo qual o dispositivo separa os seres humanos da sua relação imediata com o ambiente.

O distúrbio das máquinas de governo² atuais é observado na não produção de sujeitos reais, pois o corpo a corpo entre viventes e dispositivos proporciona uma indiferenciação entre subjetivação e dessubjetivação, cujo produto é um indivíduo espectral. Esse é o paradoxo pelo qual a política presente caminha.

Novos sujeitos deveriam ser a consequência do contato incessante entre substância e aparelhos dispositivos. Entretanto, com a proliferação ilimitada destes últimos, o produto não cede lugar a uma nova individualidade, visto que a identidade pessoal é disfarçada (AGAMBEN, 2009). Impede-se o desenvolvimento de um círculo entre ser e o ambiente que o rodeia, comprometendo o surgimento de outros sujeitos e a capacidade de construir um novo cosmo.

Nesse sentido, os aparatos políticos são formulados para constranger os seres às diretrizes do poder, apresentando três significados usuais: jurídico estrito, tecnológico e militar. O primeiro se materializa em trechos que estão textualmente em uma decisão, mas que excedem os limites da motivação apresentados na sentença. Ou ainda, em normas que informam situações permitidas e reprováveis, e decidem antecipadamente, sem qualquer apreciação da situação que subjaz (AGAMBEN, 2009).

\footnotetext{
${ }^{2}$ Leia-se: dispositivos. Definição apresentada pelo autor trabalhado.
} 
O sentido tecnológico espelha a forma pela qual um mecanismo de governo está aparelhado, os componentes que o integram e por prolongamento, o próprio dispositivo. E por último, o significado militar indica um conjunto de meios ordenados para um propósito (AGAMBEN, 2009).

Reunidas essas perspectivas centrais, Agamben (2009, p. 40) define o dispositivo como “[...] qualquer coisa que tenha de algum modo a capacidade de capturar, orientar, determinar, interceptar, modelar, controlar e assegurar os gestos, condutas, opiniões e discursos dos seres viventes.”.

Na definição exteriorizada é atribuído o papel do artefato bipolítico nos governos contemporâneos, capturar os seres viventes às relações de mando. Dessa forma, os dispositivos atuam modelando e controlando todos os momentos da vida dos indivíduos. Nesta linha de entendimento, pode ser explicado o crescimento da gestão sobre a vida dos indígenas brasileiros por este emaranhado de mecanismos de poder.

Em cada criatura dócil aos comandos, substâncias/seres viventes, prosperam numerosos processos de subjetivação. Em meio a eles, sucede uma intensa confusão de sujeitos que, ao fim, resulta em algo fantasioso (AGAMBEN, 2009). Logo, o conjunto de dispositivos, não só a suspensão de segurança, que recaem por cima da carne aborígene, conduz a uma dessubjetivação, a consagração da vida nua personificada no índio brasileiro.

É assinalada como saída, pelo escritor discutido neste estudo, um resgate da essência/ser e das práxis/ação, que foram constantemente desconectadas, com o fito de devolvêlas a um mundo de uso partilhado através da profanação. Esta reconduz o que pertenceria ao sagrado ou religioso ao uso e propriedade do mundo terreno. Nos termos de Agamben (2009, p.45), “a profanação é o contradispositivo que restitui ao uso comum aquilo que o sacrifício tinha separado e dividido".

Para encerrar este subitem, cumpre fixar parâmetros para a compreensão desse contra artefato, sendo imperativo exibir a distinção entre alguns vocábulos, realizada pelo respectivo pensador: sacrilégio, consagrar, profanar e religião. Respectivamente, sacrilégio é ação que transgrede a reserva particular dos seres celestes sobre bens; consagrar é conduzir recursos do campo humano ao sagrado; profanar é acompanhar a transferência de meios do ambiente divino para o terreno e finalmente, religião é a materialização dogmática que subtrai os recursos do uso coletivo e os translada a uma esfera celestial (AGAMBEN, 2009). 


\subsection{Força-de-Lei}

Esta expressão tão singular, na qual a palavra lei é cortada por um x, integra um capítulo do exemplar “Estado de Exceção” de autoria de Giorgio Agamben. Força-de-léi compõe o vazio normativo que nomeia esta obra, pois naquele campo desabitado pela lei, o estado de exceção, lógica e prática se indefinem, cedendo espaço a uma violência irracional que realiza enunciados sem referência concreta.

Há um resgaste da teoria de exceção apresentada por Carl Schmitt, em dois livros divulgados no início de 1920. O intuito era denunciar uma forma de governo que permanece corrente, mas que atinge seu pleno desenvolvimento no estágio atual da humanidade. Para Schmitt, o estado de exceção se materializa com as ditaduras: comissária e soberana. Distinguem-se, porque a antecedente objetiva defender ou restituir uma constituição em vigor e a precedente, busca impor uma nova ordem constitucional.

Identifica-se a inscrição da condição excepcional em um contexto jurídico, que até então passava despercebido pelos juristas da época. Essa relação é fundamental, posto que nos períodos anormais se estabelece uma ordem (AGAMBEN, 2004). É uma articulação bastante antagônica, uma vez que aquilo que deve ser registrado na ordem jurídica é algo que é exterior a ela.

A operação dessa inscrição diferencia norma e norma de aplicação, descrita por Agamben (2004) é importante para o entendimento do relacionamento sobre o direito indígena e os órgãos judiciários, principalmente os de segundo grau. Estes órgãos em particular, na proporção em que suspendem todo o direito inerente as populações originárias. Por intermédio do instituto da suspensão de segurança, permite que a elas se aplique um direito incomum. As regras que impõe a realização de consulta prévia às populações afetadas, por exemplo, deixam de ser empregadas, mas permanecem em vigor.

Durante a suspensão do direito (como acima demonstrado), dois elementos jurídicos: norma e decisão, comportam-se com independência. Em um contexto habitual, a autonomia da segunda é reduzida pela primeira, porém em casos de exceção, a lei é anulada para a total liberdade da decisão (AGAMBEN, 2004).

O veredito cabe à figura do soberano que é externo à uma ordem normativa válida, mas que a integra. Esse desarranjo pode ser explicado, visto que a incumbência quanto a decisão que suspende o ordenamento jurídico é do senhor absoluto. Destarte, ele estar-fora e, ao mesmo tempo, pertence ao direito, já que é definido pelo mesmo (AGAMBEN, 2004). 
O momento de efetivação da norma é afastado da própria norma, criando uma zona anômala, que suspende ou anula a lei, em função de um cenário que torna possível o uso de exceções legais. Na sequência, ganha destaque o sintagma força-de-lęi, comumente no direito romano e medieval.

Essa fórmula antiga distingue eficácia e força da lei. A primeira refere-se à produção de efeitos jurídicos de todos os atos elaborados em conformidade com a legislação válida. A segunda, é relativa a posição da lei ou de outros atos equiparados a mesma, em relação às partes integrantes da ordem jurídica (AGAMBEN, 2004). Em resumo, o sintagma espelha uma preocupação com aquelas decisões ou decretos formulados pelo executivo ou judiciário que adquirem força de lei e são extremamente comuns em estados de exceção.

Decretos, medidas, disposições e decisões que não são leis no sentido formal, contudo adquirem sua potência, caracterizam o ponto nevrálgico das teorias do estado de exceção, e não a simples confusão entre poderes. Nessas situações, existem normas em vigor que não podem ser empregadas e atos que não possuem valor de lei, mas se aplicam com a intensidade dela e podem ser reivindicados por autoridades estatais, organizações revolucionárias ou instituições públicas.

Nesse jogo de interesses a grafia adequada é força-de-lẹi, dado que potência e ato estão dissociados de maneira extrema, revelando o erro em que incorre a hermenêutica de tradição teológica: associar a relação norma e situação fática, como uma operação puramente lógica (AGAMBEN, 2004). Esse procedimento é intermediado por uma atividade prática desempenhada por um ou mais sujeitos com o auxílio do direito processual ${ }^{3}$, culminando na sentença ou acórdão.

\subsection{Iustitium}

É categoria constitutiva de uma teoria sobre o estado de exceção de Agamben e nela é esclarecida a natureza jurídica dessa situação política como também o sentido, lugar e forma pela qual se relaciona com o direito. Agamben denuncia que esse elemento aparentemente não ganhou a atenção adequada dos estudiosos, porém é a chave para compreender a manifestação dos estágios excepcionais na política contemporânea.

\footnotetext{
${ }^{3}$ E nesse sentido, com a ajuda da suspensão de segurança.
} 
No direito romano, pressupunha o consultum ultimum e o tumultus. O primeiro era emitido pelo Senado e, em algumas circunstâncias, pelos magistrados e cidadãos, nas ocasiões consideradas necessárias para a salvação do Estado. O segundo, correspondia à base que sustentava o consultum ultimum, ou ainda, o contexto fático que o exigia (AGAMBEN, 2004).

O Iustitium, esse paradoxal elemento jurídico, tem sua significação semelhante à de solstitium. Este, a pausa do sol, aquele, a interrupção do direito. Tratava-se de um vazio normativo, provocado não só pela suspensão da administração judiciária, como também, pela cessação da própria ordem jurídica.

As causas pertinentes ao tulmutus, conforme a literatura da época, remontam a guerras externas, emergências, insurreições, guerras civis, etc. Tecnicamente, informam ambientes de desordem e agitação. A acepção tem nexo com o termo tumor, indicando um inchaço ou fermentação. Assim, corresponde aos quadros sociais que demandam a aplicação de medidas de exceção.

Agamben (2004) critica aqueles que buscam um caráter jurídico para o tema no estado de necessidade ou na legítima defesa do Estado, como também, no argumento "quase ditaduras”. Para o autor, a melhor explicação corresponde ao surgimento de um espaço vazio do direito, no qual interesses públicos e privados se indefinem.

É a necessidade o critério para o seu uso. Ao poder que determina sua aplicação é indiferente se recai em oposição a um inimigo ou a um cidadão. E costuma definir um quadro no qual os direitos e deveres impostos pela legislação são desconsiderados em detrimento da salvação do estado-nação (AGAMBEN, 2004). No mesmo contexto, magistrados estão desobrigados ao respeito da norma legal.

O iustitium equivale ao hiato do direito para socorrer o ordenamento jurídico. Em todas as ocasiões que se tornavam incômodas para o universo jurídico, a ordem podia ser transgredida. A zona atípica que era criada indica um lócus de refúgio, onde nem mesmo a ordem constitucional podia ingressar.

Como definir as ações humanas que se sucedem em um vazio normativo? As práticas que ocorrem após a decisão de um desembargador que aplica a suspensão de segurança, conduzindo os nativos a um campo desabitado pelo direito, estão sujeitas a quais consequências jurídicas? Os atentados à vida desses indivíduos, praticados nesse vazio normativo, não estão 
submissos ao império de uma determinação legal, pois a necessidade de manutenção da ordem ou segurança impedem o grupo étnico de acessar o direito.

Aquele que age em transgressão a um direito que está em vigor, mas que não é aplicado, não desrespeita o ordenamento, simplesmente o inexecuta. Parece inapropriado imaginar que o direito cedia uma zona de suspensão, entretanto é elemento estratégico e decisivo para ordens jurídicas contemporâneas. Nesse campo de indefinição jurídica, aplica-se a ideia de força-de-lěi, dado que a interrupção legal viabiliza esse elemento místico (AGAMBEN, 2004).

\subsection{Vida Nua}

É a vida dos seres humanos exposta a uma dualidade de exceções, visto que se encontra fora das esferas do direito e do divino. Nesse aspecto, apresenta as seguintes características: impunidade da morte e a impossibilidade de sacrifício. A agressão praticada contra a vida deste ser, condenado à sacer, ou melhor, sacralizado, não constitui violação ao direito e nem sacrilégio ao divino (AGAMBEN, 2010).

Sua topologia desenha uma dupla exclusão e dual captura, pois “[...] como na exceção soberana, a lei se aplica de fato ao caso excepcional desaplicando-se, retirando-se deste, do mesmo modo o homo sacer pertence ao Deus na forma da insacrificabilidade e é incluído na comunidade na forma da matabilidade.” (AGAMBEN, 2010, p.84). Portanto, sacer ${ }^{4}$ é aquele que não pode ser entregue ao divino, todavia está sujeito a matança, sem que isso constitua ilicitude.

Seu caráter singular é a violência ao qual está contida, não sendo sancionável pelo ordenamento jurídico ou pelo divino. Intimamente conexa à estrutura do poder soberano, visto que nessa esfera limite do agir humano, é possível matar sem cometer homicídio ou celebrar sacrifício. Desta ideia, Agamben expõe a vida nua, que significa uma vida submissa ao poder de morte do soberano e exposta ao total abandono. Neste sentido, é possível entender os autóctones nacionais como personificadores dessa tipologia de vida.

As extremidades da ordem política estão ocupadas por imagens simétricas e correlatas: o soberano e o sacer. Este, identifica todos os indivíduos que são potencialmente sacer. Aquele,

\footnotetext{
${ }^{4}$ O homo sacer é o indivíduo que porta uma vida nua, uma vida que se encontra no meio de dois extremos, a zoé e a bios. A primeira, é uma manifestação de vida comum a todos os seres viventes (animais, pessoas ou deuses). A segunda, indica uma forma de viver exclusiva de um indivíduo ou grupo.
} 
é sobre quem todos os homens atuam como soberanos. Por esse ângulo, a sacralidade é nomeada relação política originária, pois é responsável pela inscrição da vida nua na ordem vigente, por meio do sintagma homo sacer. A matabilidade incondicionada da vida sacra configura a inserção da existência humana nos cálculos da máquina governamental (AGAMBEN, 2010).

\subsection{Povo - povo}

O sentido político da terminologia povo contém a noção daqueles que estão excluídos. Dessa forma, é conceito dual que revela tanto um corpo político ou conjunto de cidadãos, quanto aqueles que pertencem ao grupo de deserdados e pobres. Desta forma, povo compreende o titular da soberania, como também os que o poder público aconselha eliminar (AGAMBEN, 2015).

Essa dualidade de significados não é rara, e permite ao autor refletir acerca da natureza do termo e suas finalidades no panorama político moderno. Portanto, povo não expressa um sujeito com unidade política, mas uma articulação dialética entre dois extremos. Povo, grafado com inicial em caixa alta, como sinônimo de corpo político integral. E povo, em minúsculo, indica um subconjunto com fragmentos de vidas necessitadas.

De um lado, a completa inclusão, do outro, aqueles que permanecem sem esperança. Aos primeiros, é reservado o poder soberano, aos últimos, o campo ${ }^{5}$, um espaço de anomia onde cumprem o banimento social. Isso significa que há um movimento duplo, articulando as terminações. Dentro da categoria povo, é possível reconhecer tantas outras peças indispensáveis do pensamento agambiano, “[...] vida nua (povo) e existência política (Povo), exclusão e inclusão, zoé e bios.” (AGAMBEN, 2015, p. 37).

O elemento filosófico que se analisa neste item, preserva em seu interior a "fratura biopolítica fundamental”. É importante salientar que a vida nua está presente, mas não pertence ao conjunto do qual participa, vez que ocorrem contínuas redefinições, por meio: da língua, sangue, território e da exclusão. Essa cisão originária, segrega radicalmente, ao tempo em que mantém a unidade.

Tal oposição é acelerada no atual estágio da vida política global. Assim, “[...] o nosso tempo não é senão a tentativa - implacável e metódica - de atestar a cisão que divide o povo,

\footnotetext{
${ }^{5}$ É um espaço de exceção onde se realiza a mais absoluta condicio inhumana. Ele integra uma parcela do território que escapa do alcance da lei normalmente válida para todo o restante. Todos que estão nesse ambiente, foram incluídos para a mais violenta exclusão.
} 
eliminando radicalmente o povo dos excluídos.” (AGEMBEN, 2015, p. 39). A obstinação pelo desenvolvimento nacional integra a proposta biopolítica de alcançar um povo sem cisão. Para tal fim, entretanto, é necessário eliminar os oprimidos, da mesma forma que judeus e ciganos se tornaram o símbolo da solução final nazista.

Todo o processo de eliminação biológica que atende aos interesses do programa de desenvolvimento capitalista, busca transformar o corpo das camadas mais vulneráveis da sociedade em pura vida nua, e o índio brasileiro não está excluído dessa atividade violenta.

\section{O INSTITUTO DA SUSPENSÃO DE SEGURANÇA}

Este é incidente processual, no qual Ministério Público e pessoas jurídicas de Direito Público ou concessionárias do poder público buscam suspender os efeitos de decisão, sentença ou acórdão, por intermédio da suspeita de grave risco à ordem, economia, saúde ou segurança. Seu pedido deve ser direcionado ao presidente do Tribunal competente para o conhecimento do recurso cabível.

Originariamente, a suspensão de segurança foi prevista para tornar sem efeito as decisões liminares e sentenças em sede de mandados de segurança; por isso a escrita "pedido de suspensão de segurança” ganhou popularidade. Ao longo dos anos, passou a ser evocado em quase todas as decisões prolatadas em desfavor da Fazenda Pública, sobretudo nas causas que tratam da realização de projetos econômicos, financiados com dinheiro público, em terras indígenas (SANTOS; GOMES, 2015).

Sua previsão legal está disposta em inúmeras legislações, dentre elas: Lei nº 7.347/85 - suspensão de liminar em Ação Civil Pública (artigo 12, §1); Lei n 8.437/92 - suspensão de liminar ou sentença em Ação Popular, Ação Cautelar e ACP ${ }^{6}$ - (artigo 4); Lei nº 9.494/97 disciplina a aplicação de tutela antecipada contrária a Fazenda Pública (artigo 1); Lei $n^{\circ}$ 12.016/09 - versa sobre Mandado de Segurança Individual e Coletivo (artigo 15); Lei $n^{\circ}$ 9.507/97 - regula o Habeas Data (artigo 16); Lei n ${ }^{\circ}$ 191/1936 - regula o processo do Mandado de Segurança; Lei $n^{\circ}$ 8.038/1990 - suspende despachos fundamentados, decisão liminar e sentença em contraposição aos interesses do Poder Público em sede do STJ e STF ${ }^{7}$; Súmula 626 do STF - trata da ultratividade da decisão que suspende os efeitos das liminares; etc.

\footnotetext{
${ }^{6}$ Ação Civil Pública.

${ }^{7}$ Respectivamente, Superior Tribunal de Justiça e Supremo Tribunal Federal.
} 
Discute-se a natureza da decisão que concede o elemento jurídico apontado neste item, caráter político ou jurisdicional. O STJ entende tratar-se de um juízo político ${ }^{8}$, devido à lesividade à ordem, segurança, economia e saúde provocada por atividade jurisdicional que confere decisão liminar. Portanto, é um crivo político que identifica, na tutela antecipada deferida, uma ameaça ao interesse público. O efeito mais marcante dessa corrente é a impossibilidade de recurso especial, visto não se tratar de atividade jurisdicional.

Aqueles que defendem uma compreensão distinta, como Soares (2011), alegam que a concessão da suspensão não pode ser de ofício, somado a impossibilidade de alterar um pronunciamento jurídico por ato político. Entretanto, sustentam o impedimento a recursos especiais e extraordinários, pois o instituto não analisa o mérito da demanda principal.

É ponto polêmico na doutrina a vedação ao exame de mérito, porém o STF pacificou a matéria ao exigir um juízo mínimo para a deliberação ${ }^{9}$ por meio da demonstração da fumaça de bom direito e perigo na demora. Contra a decisão que atende ao pedido de suspensão, caberá apenas agravo de instrumento no prazo limítrofe de 5 dias, mas havendo o seu deferimento a Fazenda Pública pode solicitar outra suspensão de segurança ao Presidente do tribunal competente para apreciar recurso a esse segundo julgamento. Por outro lado, não promovendo o agravo, deste juízo não haverá recurso disponível à parte vencida.

A suspensão de segurança foi inserida no direito brasileiro durante a “era Vargas” (lei $n^{0}$ 191/1936) e concretiza-se com a ditadura militar por meio da lei $n^{\circ} 4348 / 1964$. Nesse contexto, o Brasil atravessava profundas transformações econômicas, especialmente com o processo de industrialização. Assim, a partir da sua gênese, o instrumento processual já sinalizava uma aproximação dos interesses econômicos. Nesse sentido, SANTOS e GOMES

\footnotetext{
8 Conforme entendimento firmado no julgamento do agravo em recurso especial, processo $\mathrm{n}^{\circ}$ AREsp 977317BA2016/0231162-1, em 28 de agosto de 2017, sob a relatoria da ministra Assusete Magalhães. STJ. Agravo em Recurso Especial $\mathbf{n}^{0} \mathbf{9 7 7 . 3 1 7}-$ BA. Disponível em:< https://stj.jusbrasil.com.br/jurisprudencia/492973935/agravo-em-recurso-especial-aresp-977317-ba-20160231162-1>. Acesso em: 01 de março de 2018.

${ }^{9}$ Como no julgamento do Agravo Regimental no STA73, de relatoria da Ministra ELLEN GRACIE, em 17 de março de 2008. SJT. AGRAVO REGIMENTAL. SUSPENSÃO DA EXECUÇÃO DE TUTELA ANTECIPADA: ARTS. $4^{\circ}$, CAPUT, DA LEI 8.437/92 E $1^{\circ}$ DA LEI 9.494/97. PRESTAÇÃO DO SERVIÇO DE TRANSPORTE RODOVIÁRIO INTERESTADUAL DE PASSAGEIROS. LICITAÇÃO: ARTS. 21, XII, "e", E 175 DA CONSTITUIÇÃO DA REPÚBLICA. DEMONSTRAÇÃO DOS REQUISITOS OBJETIVOS PARA O DEFERIMENTO DA SUSPENSÃO DA EXECUÇÃO DO ACÓRDÃO: LESÕES ÀS ORDENS JURÍDICA, ADMINISTRATIVA E À ECONOMIA PÚBLICA. JUÍZO MÍNIMO DE DELIBAÇÃO. EFEITO MULTIPLICADOR. MINISTRO RELATOR(A) ELLEN GRACIE. 2008. Disponível em:<http://www.stf.jus.br/portal/jurisprudencia/visualizarEmenta.asp?s1=000088408\&base=baseAcordaos $>$. Acesso em: 01 de abril de 2018.
} 
(2015, p. 7) “ainda que o instituto tenha sido utilizado em prol de interesses efetivamente públicos, sua origem e seu aprimoramento têm conexões diretas em benefício do capital e contra a efetivação de direitos humanos e do papel do Poder Judiciário.”.

Sua aplicação tem revelado uma forte dimensão política no Judiciário brasileiro. O bioma amazônico, devido à sua biodiversidade, tem atraído inúmeras atividades exploratórias, notadamente o agronegócio. A viabilidade desses empreendimentos depende da construção de alguns projetos de infraestrutura: rodovias, hidrelétricas, ferrovias, hidrovias e outros. Nos últimos anos, o Poder Público viabilizou inúmeras obras de grande impacto, mediante o Programa de Aceleração ao Crescimento - PAC, o Plano Amazônia Sustentável - PAS e a Inciativa para Integração da Infraestrutura Regional Sul Americana - IIRSA (SANTOS; GOMES, 2015).

Um exemplo paradigmático é a construção da Usina de Belo Monte, na qual mais de 10 ações civis públicas e uma Ação Direta de Inconstitucionalidade, ajuizada pelo Procurador Geral da República, buscaram, sem sucesso, paralisar o andamento das obras. As justificativas apresentadas eram ausência de consulta às populações afetadas e a legalidade duvidosa da licença ambiental obtida (SANTOS; GOMES, 2015).

Nem mesmo o fato da licença prévia de Belo Monte ter sido concedida sem respaldo do próprio IBAMA interrompeu a execução. No período, a suspensão de segurança foi utilizada 6 vezes sob o pretexto de ameaça à ordem e economia pública. Este, não foi o único caso que afetou a vida de populações indígenas.

Ao longo dos rios Tapajós e Jamanxim, no Estado de Pará, está previsto a construção de um complexo formado por várias hidrelétricas. O caso se insere no contexto discutido, pois as populações tradicionais que habitam o local não foram examinadas acerca da concordância ou não de empreendimentos em suas terras ancestrais. O IBAMA autorizou o ingresso de pesquisadores para coleta de material biológico na área, antes da oitiva dos sujeitos atingidos.

Diversas tentativas buscaram suspender a obra até a escuta das populações nativas, bem como, exigiam a realização de Avaliação Ambiental Integrada e Avaliação Ambiental estratégica para que fossem publicados os impactos da construção e se oferecessem subsídios à escolha dos povos indígenas (SANTOS; GOMES, 2015). A etnia Mundukuru, uma das mais afetadas, manifestou inúmeras vezes a não conveniência dos trabalhos de levantamento de 
dados através de nota pública em episódio que envolveu a detenção de estudiosos pelos aborígenes $^{10}$.

O processo de demarcação das terras, do grupo indígena mencionado no parágrafo anterior tem enfrentado intensos atrasos, porque seu território está estrategicamente no “caminho” da edificação da usina de São Luiz de Tapajós, fato que foi atestado pela FUNAI em manifestações que buscaram justificar a demora da finalização do processo demarcatório (SANTOS; GOMES, 2015).

A construção da estrada de ferro Carajás no Maranhão é outro exemplo para o tema discutido, pois são 27 municípios impactados pela obra (SANTOS; GOMES, 2015). O episódio recebeu atenção, uma vez que o pedido de suspensão de segurança concedido pelo Poder Judiciário foi realizado por pessoa jurídica de direito privado, Vale S.A., ampliando o rol originário de legitimados a propor o instituto. Nesse caso, o povo Awá-Guajá é um dos mais afetados, visto que se constituem em uma das últimas comunidades nômades e coletoras que vivem no Brasil.

Por derradeiro, fica constatado o uso do instrumento da suspensão de segurança, especialmente contra os povos nativos, como mecanismo de exceção ao ordenamento jurídico brasileiro, que assegura a consulta previa às populações indígenas de maneira especial na Constituição Federal (artigo 231, §3) e na Convenção 169 da OIT.

A carta magna brasileira no artigo 231, parágrafo terceiro, reconhece o direito originário dos índios sobre as terras que tradicionalmente ocupam, informando que o aproveitamento de recursos hídricos na área, só poderá ser efetivado, após a orientação das comunidades afetadas.

Os artigos 6º 15 da Convenção 189 da OIT (1989) comunicam que os governos deverão consultar os povos interessados, sempre que forem previstas medidas legislativas ou administrativas que possam afetar a vida dos mesmos. No trecho que versa sobre o aproveitamento de recursos existentes nas terras, adverte acerca da necessidade de oitiva destes povos, antes da execução ou autorização de qualquer programa de exploração.

$\mathrm{O}$ acesso à justiça previsto no artigo $5^{\circ}, \mathrm{XXXV}$ da Constituição Federal e no artigo 8 do Pacto São José da Costa Rica, documento normativo do Sistema Interamericano de Direitos

\footnotetext{
${ }^{10}$ FOLHA DE SÃO PAULO. Índios Mundukurus capturam três pesquisadores no Rio Tapajós no Pará. 2013. Disponível em:< http://www1.folha.uol.com.br/poder/2013/06/1299843-indios-mundurucus-capturam-trespesquisadores-no-rio-tapajos-no-para.shtml>. Acesso em: março de 2018.
} 
Humanos, é violado pela suspensão de segurança ao impedir que os povos primitivos recorram ao judiciário, na hipótese de projetos econômicos que possam comprometer suas vidas.

\section{CONSIDERAÇÕES FINAIS}

A partir da expressão grega, oikonimia, a teologia cristã adota uma postura que aconselha a divisão de Deus, o soberano do espaço religioso, em ser e ação, para a gestão adequada do mundo dos homens. Progressivamente, as partes que integram a figura divina se afastam, ocasionando processos de subjetivação, tentativas de elaboração de novos sujeitos, sem fundamento na essência, dado que a prática se distanciou dela para que se consubstanciasse a devida administração doméstica.

Essa ideia penetra no campo político e se torna o alicerce mais importante dos governos contemporâneos. A gerência recai sobre o mundano, não apenas o sobrenatural. A chave moderna que segrega substância e ação são os dispositivos biopolíticos, conduzindo homens e mulheres a processos de formulação de novos sujeitos. Entretanto, não nascem sujeitos reais, somente surgem os espectrais. Estes últimos, são incapazes de conceber um novo mundo, onde indivíduos possam compor uma unidade política ativa e exigente de direitos.

O mundo existente sofre uma cisão em seres viventes e dispositivos. Resume-se a pessoas com identidade sob disfarce e mecanismos de captura, qualificados para a determinação, interceptação e controle dos gestos, opiniões e discursos da humanidade. Entre seus usos mais habituais estão a criação de leis, que definem situações aceitas e reprováveis, permitindo aos magistrados tanto decidirem antecipadamente, sem avaliação meritória da situação que subjaz à norma quanto ordenarem a criatividade legislativa e a atuação jurisdicional para um propósito.

No universo de dispositivos operantes, esta pesquisa propôs investigar um exemplo emblemático, a suspensão de segurança, que tem capturado o corpo do índio para torná-lo dócil aos imperativos do soberano. Ontem, a religião, através das missões jesuítas, hodiernamente, por meio do direito.

Por intermédio de uma operação que isola a norma do seu momento de aplicação, todo o direito favorável ao indígena é suspenso, sendo-lhe aplicado uma ordem incomum, que reduz a força da lei e amplia a potência da decisão. A Constituição Federal e a Convenção 169 da OIT, apesar de permanecem em vigor, perdem qualquer efeito prático. 
Essa intervenção cirúrgica no corpo social ocorre quando identificado um contexto de agitação e desordem pública, portanto, diante de um tulmutus. O critério que assinala sua utilização é a necessidade. Nesse sentido, na presença de forte resistência aborígene a projetos que buscam a salvação da ordem e economia nacional, está configurado seu emprego. É indiferente a quem recai a medida, inimigo ou cidadão, por isso o índio se insere na extensão dela. O cenário que desenha é de um hiato no ordenamento jurídico: leis sendo postas de lado para a salvação do Estado. Aqueles que atuam nessa zona, não agem ilicitamente, apenas inexecutam a legislação. Por isso, não há como responsabilizar empresas que violentam a vida indígena para a execução de projetos exploratórios.

Desta forma, os membros dos povos originários estão sujeitos a uma dupla excepcionalidade: impunidade da matança e insacrificabilidade da vida. São expostos ao mais violento abandono, para marcar o limite de atuação do soberano, o poder de agir sobre seus corpos. O efeito da suspensão assemelha-se ao do iustitium, fazendo surgir uma zona anômala ou vazio normativo que, paulatinamente, inscreve o índio na sacralidade.

Esse indivíduo compõe o titular da soberania, pois integra uma das raças responsáveis pela formação do Povo brasileiro, e simultaneamente, é aquele que o Poder Público aconselha eliminar, conduzindo-o, ao campo, espaço onde cumpre o banimento social. De membro da unidade política, torna-se povo, categoria composta por abandonados. A redefinição do corpo social é empreendida pela exclusão, que se opera intermediada pelo dispositivo "suspensão de segurança”.

A obstinação pelo desenvolvimento nacional desperta o propósito biopolítico de alcançar um povo sem cisão, eliminando os oprimidos. O exemplo categórico na Europa, foram judeus e ciganos. A amostra na América, ontem e hoje, são os índios. Como saída, aponta Agamben (2009) é profanar o direito, restituí-lo ao uso comum, ao acesso do nativo.

\section{REFERÊNCIAS}

AGAMBEN, Giorgio. Estado de Exceção. Tradução de Iraci D. Poleti. São Paulo: Boitempo Editorial, 2004. 
AGAMBEN, Giorgio. HOMO SACER: o poder soberano e a vida nua. Tradução de Henrique Burigo. Belo Horizonte: UFMG, 2010.

AGAMBEN, Giorgio. Meios sem fim: notas sobre a política. Tradução de Cláudio Oliveira. Belo Horizonte: Autêntica, 2015.

AGAMBEN, Giorgio. O que é contemporâneo? e outros ensaios. Tradução de Vinicius Nicastro Honesko. Chapecó: Argos, 2009.

BRASIL. Constituição (1988). Constituição da República Federativa do Brasil. Brasília, DF: Senado, 1988.

FOLHA DE SÃO PAULO. Índios Mundukurus capturam três pesquisadores no Rio Tapajós no $\quad$ Pará. $2013 . \quad$ Disponível em:< http://www1.folha.uol.com.br/poder/2013/06/1299843-indios-mundurucus-capturam-trespesquisadores-no-rio-tapajos-no-para.shtml>. Acesso em: março de 2018.

OIT. Convenção $\mathbf{n}^{\circ} 169$ sobre povos indígenas e tribais e Resolução referente à ação da OIT. Brasília: $\quad 2011 . \quad$ OIT, Disponível em:< http://portal.iphan.gov.br/uploads/ckfinder/arquivos/Convencao_169_OIT.pdf>. Acesso em: março de 2018.

ORGANIZAÇÃO INTERNACIONAL DO TRABALHO. Convenção n ${ }^{\mathbf{0}} \mathbf{1 6 9} .1989$. Disponível em: $<\quad$ http://www.planalto.gov.br/ccivil_03/_ato20042006/2004/decreto/d5051.htm>. Acesso em: março de 2018.

RIBEIRO, Darcy. Os índios e a Civilização: a integração das populações indígenas no Brasil moderno. 7 ed. São Paulo: Global, 2017.

RICHARDSON, Roberto Jarry. Pesquisa Social: Métodos e Técnicas. Colaboração de José Augusto de Souza Peres et al. 3. ed. São Paulo: Atlas, 1999.

SANTOS, Boaventura de Souza. Uma Cartografia Simbólica das Representações Sociais: prolegómenos a uma concepção pós-moderna do direito. In: Revista Crítica de Ciências 
Sociais, n. 24, março de 1988. Disponível em: < http://www.boaventuradesousasantos.pt/media/pdfs/Cartografia_simbolica_RCCS24.PDF>. Acesso em: março de 2018.

SANTOS, Layza Queiroz; GOMES, Erina Batista. Suspensão de Segurança, neodesenvolvimentismo e violações de direitos humanos no Brasil. Curitiba: Monalisa, 2015. Disponível em:< http://terradedireitos.org.br/acervo/relatorios-e-pareceres/suspensaode-seguranca-neodesenvolvimentismo-e-violacoes-de-direitos-humanos-no-brasil/19640>.

Acesso em: março de 2018.

SOARES, Leonardo Oliveira. O Requerimento de Suspensão de Eficácia de Liminar como Desdobramento do Direito Fundamental do Réu à Tutela Jurisdicional Adequada. In: Revista EMERJ, n. 14, n. 55, p. 179-190, mai. 2011. Rio de Janeiro: EMERJ, 2011.

SJT. AGRAVO REGIMENTAL. SUSPENSÃO DA EXECUÇÃO DE TUTELA ANTECIPADA: ARTS. 4 $4^{\circ}$, CAPUT, DA LEI 8.437/92 E $1^{\circ}$ DA LEI 9.494/97. PRESTAÇÃO DO SERVIÇO DE TRANSPORTE RODOVIÁRIO INTERESTADUAL DE PASSAGEIROS. LICITAÇÃO: ARTS. 21, XII, "e", E 175 DA CONSTITUIÇÃO DA REPÚBLICA. DEMONSTRAÇÃO DOS REQUISITOS OBJETIVOS PARA O DEFERIMENTO DA SUSPENSÃO DA EXECUÇÃO DO ACÓRDÃO: LESÕES ÀS ORDENS JURÍDICA, ADMINISTRATIVA E À ECONOMIA PÚBLICA. JUÍZO MÍNIMO DE DELIBAÇÃO. EFEITO MULTIPLICADOR. MINISTRO RELATOR(A) ELLEN GRACIE. $2008 . \quad$ Disponível em: <http://www.stf.jus.br/portal/jurisprudencia/visualizarEmenta.asp?s1=000088408\&base=b aseAcordaos>. Acesso em: 01 de abril de 2018.

STJ. Agravo em Recurso Especial $\mathbf{n}^{\mathbf{0}} \mathbf{9 7 7 . 3 1 7}$ - BA. Disponível em:< https://stj.jusbrasil.com.br/jurisprudencia/492973935/agravo-em-recurso-especial-aresp977317-ba-2016-0231162-1>. Acesso em: 01 de março de 2018. 